\title{
Originals
}

\section{Effects of Diet on the Cellular Insulin Binding and the Insulin Sensitivity in Young Healthy Subjects}

\author{
H. Beck-Nielsen, O. Pedersen, and N. Schwartz Sørensen \\ Medical Department III and Department of Clinical Chemistry, County Hospital, Tage Hansensgade, Århus, and Nutrition Laboratory, \\ Institute of Hygiene, University of Aarhus, Denmark
}

Summary. To ascertain whether the effects of diet on glucose tolerance and insulin sensitivity are mediated through changes of insulin receptors we have studied insulin binding to monocytes in 24 young volunteers (4 groups of 6) during 2 week periods of different dietary regimens. In group 1 and 2 the subjects had their usual diet plus $1000 \mathrm{kcal}$ per day from sucrose or fat, respectively. Group 3 had an isocaloric diet with a low-sucrose content, while group 4 ate low-fat high carbohydrate diets. Before change of diet the total group of volunteers showed an inverse correlation between insulin binding and average daily sucrose intake $(\mathrm{R}=-0.52, \mathrm{p}<0.01)$. An excessive sucrose consumption (group 1) was associated with a reduction both of insulin binding $(\mathrm{p}<0.05)$ and insulin sensitivity $(p<0.05)$. The changes of the two variables were parallel $(R=0.95, p<0.05)$. An abundant fat intake (group 2) was also accompanied by a decrease of insulin binding $(\mathrm{p}<0.05)$. However, insulin sensitivity was unaltered $(\mathrm{p}>0.1)$. A rise of insulin binding $(p<0.05)$ followed the isocaloric, low-sucrose diet (group 3) whereas the insulin sensitivity was unchanged $(\mathrm{p}>0.1)$. After the isocaloric, low-fat diet (group 4) no significant change of insulin binding occurred $(p>0.1)$ whereas the insulin sensitivity increased $(p<0.05)$. We conclude that diet and especially the dietary sucrose content affect insulin binding to human monocytes. Evidence is presented that changes of insulin sensitivity following hyperalimentation of sucrose may be induced through alterations of insulin receptors.

Key words: Insulin receptors, insulin sensitivity, diet, sucrose, monocytes.
The composition and quantity of diet is of importance for glucose tolerance and insulin sensitivity. An isocaloric diet high in polysaccharides but low in fat increases glucose tolerance in normal subjects whereas the opposite event occurs after intake of a diet high in fat $[1,2,3]$. Intense hyperalimentation is associated with an increase of the plasma insulin level and a deterioration of glucose tolerance and insulin sensitivity [4]. A high-sucrose diet leads to impaired glucose tolerance and induces a concomitant rise in the fasting plasma insulin concentration [5].

Patients with hyperinsulinism and impaired glucose tolerance and insulin sensitivity are often found to have decreased cellular insulin binding [6]. However, both insulin binding and insulin sensitivity rise when the patients are treated with a hypocaloric diet $[6,7]$. Moreover, a positive correlation between insulin binding and insulin sensitivity has been shown both in normal and obese subjects [8,9]. Cellular insulin binding may thus be of importance in determining insulin sensitivity and changes in this binding could explain, in part, the influence of diet on glucose tolerance and insulin sensitivity. We have therefore studied changes of insulin binding to monocytes and changes of insulin sensitivity in young adults under different dietary conditions.

\section{Material and Methods}

\section{Normal Volunteers}

28 young healthy persons, 7 males and 21 females, aged $23-33 \mathrm{yr}$, within $80-120 \%$ of their ideal weight were studied. There was no difference of ideal weight between males and females. All volunteers were nurses with the same degree of physical activity. Four 
Table 1. Clinical and experimental data in 5 groups of young volunteers. $n=6$ in group $1-4$ and $n=4$ in the control group

\begin{tabular}{|c|c|c|c|c|c|}
\hline & $\begin{array}{l}\text { Body } \\
\text { weight } \\
(\mathrm{kg})\end{array}$ & $\begin{array}{l}\text { Fasting } \\
\text { plasma } \\
\text { insulin } \\
(\mu \mathrm{U} / \mathrm{ml})\end{array}$ & $\begin{array}{l}\text { Fasting } \\
\text { plasma } \\
\text { glucose } \\
(\mathrm{mmol} / \mathrm{l})\end{array}$ & $\begin{array}{l}\mathrm{k}_{\mathrm{IVITT}}^{\mathrm{b}} \\
10^{-2} \mathrm{~min}^{-1}\end{array}$ & $\begin{array}{l}\text { Specific } \\
\text { cell bound } \\
\text { fraction }^{c} \\
\times 10^{-2}\end{array}$ \\
\hline \multicolumn{6}{|c|}{$\begin{array}{l}\text { Group } 1 . \text { Hypercaloric diet with } \\
\text { high sucrose content }\end{array}$} \\
\hline $\begin{array}{l}\text { Before study } \\
\text { After } 7 \text { days } \\
\text { After } 14 \text { days }\end{array}$ & $\begin{array}{l}56.6 \pm 3.0 \\
57.5 \pm 2.9 \\
58.3 \pm 3.0\end{array}$ & $\begin{array}{l}6 \pm 1 \\
8 \pm 1 \\
9 \pm 1^{a}\end{array}$ & $\begin{array}{l}4.6 \pm 0.2 \\
5.1 \pm 0.1^{\mathrm{a}} \\
5.1 \pm 0.1^{\mathrm{a}}\end{array}$ & $\begin{array}{l}4.2 \pm 0.4 \\
- \\
3.3 \pm 0.5^{\mathrm{a}}\end{array}$ & $\begin{array}{l}3.3 \pm 0.2 \\
2.1 \pm 0.2^{\mathrm{a}} \\
2.0 \pm 0.1^{\mathrm{a}}\end{array}$ \\
\hline \multicolumn{6}{|c|}{$\begin{array}{l}\text { Group } 2 \text {. Hypercaloric diet with } \\
\text { high fat content }\end{array}$} \\
\hline $\begin{array}{l}\text { Before study } \\
\text { After } 7 \text { days } \\
\text { After } 14 \text { days }\end{array}$ & $\begin{array}{l}61.4 \pm 4.2 \\
62.2 \pm 4.3 \\
62.8 \pm 4.3^{\mathrm{a}}\end{array}$ & $\begin{array}{l}6 \pm 1 \\
6 \pm 1 \\
6 \pm 1\end{array}$ & $\begin{array}{l}5.0 \pm 0.1 \\
5.1 \pm 0.1 \\
5.2 \pm 0.1\end{array}$ & $\begin{array}{l}4.6 \pm 0.3 \\
- \\
4.8 \pm 0.6\end{array}$ & $\begin{array}{l}2.9 \pm 0.3 \\
2.3 \pm 0.2^{\mathrm{a}} \\
2.3 \pm 0.2^{\mathrm{a}}\end{array}$ \\
\hline \multicolumn{6}{|c|}{$\begin{array}{l}\text { Group 3. Isocaloric with low } \\
\text { sucrose content }\end{array}$} \\
\hline $\begin{array}{l}\text { Before study } \\
\text { After } 7 \text { days } \\
\text { After } 14 \text { days }\end{array}$ & $\begin{array}{l}57.4 \pm 3.2 \\
58.0 \pm 2.7 \\
57.0 \pm 3.0\end{array}$ & $\begin{array}{l}6 \pm 1 \\
5 \pm 1 \\
4 \pm 1\end{array}$ & $\begin{array}{l}5.3 \pm 0.2 \\
4.8 \pm 0.1 \\
5.0 \pm 0.1\end{array}$ & $\begin{array}{l}4.4 \pm 0.3 \\
- \\
4.1 \pm 0.6\end{array}$ & $\begin{array}{l}2.8 \pm 0.3 \\
2.6 \pm 0.3 \\
3.8 \pm 0.4^{a}\end{array}$ \\
\hline \multicolumn{6}{|c|}{$\begin{array}{l}\text { Group 4. Isocaloric diet with low } \\
\text { fat content }\end{array}$} \\
\hline $\begin{array}{l}\text { Before study } \\
\text { After } 7 \text { days } \\
\text { After } 14 \text { days }\end{array}$ & $\begin{array}{l}68.5 \pm 4.1 \\
68.2 \pm 3.9 \\
68.0 \pm 3.4\end{array}$ & $\begin{array}{l}8 \pm 1 \\
8 \pm 1 \\
8 \pm 1\end{array}$ & $\begin{array}{l}5.2 \pm 0.1 \\
4.6 \pm 0.1 \\
4.8 \pm 0.1\end{array}$ & $\begin{array}{l}3.8 \pm 0.2 \\
- \\
4.6 \pm 0.4^{a}\end{array}$ & $\begin{array}{l}2.8 \pm 0.3 \\
2.5 \pm 0.1 \\
3.2 \pm 0.4\end{array}$ \\
\hline $\begin{array}{l}\text { Controls } \\
\text { Before study } \\
\text { After } 7 \text { days } \\
\text { After } 14 \text { days }\end{array}$ & $\begin{array}{l}59.5 \pm 2.8 \\
59.3 \pm 2.6 \\
59.6 \pm 2.9\end{array}$ & $\begin{array}{l}5 \pm 1 \\
- \\
5 \pm 1\end{array}$ & $\begin{array}{l}4.6 \pm 0.2 \\
- \\
4.6 \pm 0.2\end{array}$ & $\begin{array}{l}- \\
- \\
-\end{array}$ & $\begin{array}{l}3.3 \pm 0.3 \\
3.1 \pm 0.5 \\
3.3 \pm 0.4\end{array}$ \\
\hline
\end{tabular}

a The values marked "a" are significantly $(\mathrm{p}<0.05)$ higher than the initial values

b $\mathrm{K}_{\text {IVITT }}$ is the rate constant for the fall in plasma glucose concentration after intravenous injection of $0.05 \mathrm{U}$ insulin per kg body weight

c The specific cell bound fraction is the fraction of ${ }^{125} \mathrm{I}$-insulin bound at the tracer insulin concentration

Table 2. Average daily intake of food (mean \pm SEM) before and during the study period in 5 groups of young volunteers

\begin{tabular}{|c|c|c|c|c|c|c|}
\hline & $\begin{array}{l}\text { Total } \\
\text { calories } \\
\text { (kcal/day) }\end{array}$ & $\begin{array}{l}\text { Total carbo- } \\
\text { hydrates } \\
\text { (kcal/day) }\end{array}$ & $\begin{array}{l}\text { Sucrose } \\
\text { (kcal/day) }\end{array}$ & $\begin{array}{l}\text { Protein } \\
\text { (kcal/day) }\end{array}$ & $\begin{array}{l}\text { Fat } \\
\text { (kcal/day) }\end{array}$ & $\begin{array}{l}\text { Alcohol } \\
\text { (kcal/day) }\end{array}$ \\
\hline \multicolumn{7}{|l|}{ Group I } \\
\hline Usual diet & $1986 \pm 172$ & $697 \pm 62$ & $168 \pm 22$ & $260 \pm 32$ & $925 \pm 98$ & $106 \pm 18$ \\
\hline High sucrose diet & $3247 \pm 194$ & $1847 \pm 101$ & $1147 \pm 39$ & $250 \pm 30$ & $1101 \pm 121$ & $50 \pm 18$ \\
\hline \multicolumn{7}{|l|}{ Group 2} \\
\hline Usual diet & $2380 \pm 309$ & $951 \pm 113$ & $268 \pm 45$ & $314 \pm 35$ & $1037 \pm 106$ & $79 \pm 15$ \\
\hline High fat diet & $3756 \pm 383$ & $986 \pm 119$ & $290 \pm 39$ & $297 \pm 34$ & $2287 \pm 184$ & $86 \pm 10$ \\
\hline \multicolumn{7}{|l|}{ Group 3} \\
\hline Usual diet & $1740 \pm 128$ & $640 \pm 66$ & $145 \pm 45$ & $235 \pm 45$ & $804 \pm 55$ & $61 \pm 18$ \\
\hline Low sucrose diet & $1700 \pm 67$ & $454 \pm 15$ & $29 \pm 10$ & $327 \pm 15$ & $890 \pm 51$ & - \\
\hline \multicolumn{7}{|l|}{ Group 4} \\
\hline Usual diet & $2037 \pm 150$ & $655 \pm 38$ & $131 \pm 13$ & $314 \pm 21$ & $949 \pm 80$ & $116 \pm 11$ \\
\hline Low fat diet & $2050 \pm 169$ & $1093 \pm 91$ & $196 \pm 15$ & $397 \pm 20$ & $560 \pm 51$ & - \\
\hline \multicolumn{7}{|l|}{ Controls } \\
\hline Usual diet & $1958 \pm 171$ & $770 \pm 82$ & $190 \pm 28$ & $372 \pm 32$ & $744 \pm 66$ & $72 \pm 12$ \\
\hline
\end{tabular}


subjects (one in each study group) received contraceptive pills. No other drugs were used. On days of examination the volunteers were transported to the hospital by car to eliminate exercise before blood sampling. Metabolic characteristics of the group are given in Table 1.

\section{Protocol}

The volunteers were randomly divided into 4 study groups, each group comprising 6 subjects, and a control group of 4 subjects. A trained dietitian instructed all attendants how to record food consumption. Records were made at the end of each meal. The food composition and the caloric content were estimated from dietary tables [10]. Following 1 week of baseline evaluation, where the volunteers were asked to continue their usual food intake, the persons in group 1 and group 2 were put on hypercaloric diets whereas the persons in group 3 and group 4 had isocaloric diets. All continued their experimental diets for 2 weeks giving daily records to the dietitian.

The subjects of group 1 were instructed to eat their normal food plus $250 \mathrm{~g}$ pure sucrose/day giving 1000 extra kcal.

The subjects of group 2 were fed their normal diet with addition of cream to main meals giving a supplement of $1000 \mathrm{kcal}$ per day. The subjects of group 3 and group 4 were fed diets giving each person the same daily energy supply as before the study. Group 3 ate a low-sucrose diet while group 4 had a low-fat diet. Table 2 gives the individual average daily intake of major constituents. Before the diet was changed (baseline period) the following variables were measured:

Body weight, fasting plasma concentrations of glucose and insulin, insulin binding to monocytes and intravenous insulin tolerance test (IVITT).

All measurements were repeated 1 week and again 2 weeks after the change of diet, except IVITT, which was repeated only after 2 weeks.

The controls continued their usual diet throughout the three week period.

Insulin: Plasma insulin concentration was measured by the radioimmunoassay of Heding [11].

Glucose: Plasma glucose concentration was measured using an otoluidine method [12].

Cell Binding Studies: One hundred and forty $\mathrm{ml}$ blood were drawn from an antecubital vein at $8.00 \mathrm{a} . \mathrm{m}$. after an overnight fast and transferred to tubes containing EDTA (dipotassium salt). Mononuclear leucocytes were isolated by gradient centrifugation [13]. The cells were washed twice and incubated in tris- $\mathrm{HCl}$ buffer $\left(25 \mathrm{mmol} / 1, \mathrm{pH} 8.0\right.$ at $\left.15^{\circ} \mathrm{C}\right)$ at a concentration of about $60 \times$ $10^{6} / \mathrm{ml}$ for $100 \mathrm{~min}$ at $15^{\circ}$ with $125 \mathrm{I}$-insulin (Novo Research Institute, Copenhagen) at a concentration of $85 \mathrm{pmol} / 1(0.5 \mathrm{ng} / \mathrm{ml})$ [13]. The specific activity of the tracer was $25-30 \mu \mathrm{Ci} / \mu \mathrm{g}$ with $0.1-0.2$ of iodine atoms per insulin molecule [14]. At this low degree of iodination more than $95 \%$ of the iodoinsulin is monoiodinated [15].

For competition studies native insulin in increasing concentrations was added to the incubation medium. At the end of the incubation period cell bound and free insulin were separated by centrifugation through silicone oil (relative density 1.04). "Specific cell bound fraction" was defined as total cell bound fraction minus non-specific cell bound fraction. Radioactivity which remained bound in the presence of an excess of native insulin at 13 umol/1 was considered "non-specific". This fraction averaged $25 \%$ of total binding. There was no significant difference between the nonspecific binding before and after dieting in the 4 groups studied. The monocytes were identified in cytocentrifuged smears stained with alpha naphthyl acetate esterase. The specific cell bound frac tion was adjusted to a standard monocyte concentration of $1.2 \times$ $10^{7} / \mathrm{ml}[16]$. There was no significant change of monocyte concentration in the five groups studied during the three week period $(p>0.1)$. All binding studies were done in duplicate.

Binding Analysis: The results of the binding studies are presented in 4 ways:

1) The specific cell bound fraction (bound/total) of insulin at the insulin tracer concentration, $85 \mathrm{pmol} / 1$.

2) The specific cell bound fraction, plotted as a function of total insulin concentration (competition curve).

3) Specific cell bound/free insulin plotted as a function of specific cell bound insulin (Scatchard plot) [17]. Maximal binding capacity $\left(R_{0}\right)$ was obtained by extrapolation of each curve to the intercept on the abscissa.

4) The concentration of native insulin necessary to reduce the specific cell bound fraction of 125 I-insulin $50 \%$ (" $50 \%$ inhibition") is for comparative studies taken as an estimate for receptor affinity (a low " $50 \%$ inhibition" indicated a high receptor affinity and vice versa).

Insulin Tolerance Test (IVITT): $0.05 \mathrm{U}$ crystalline insulin per $\mathrm{kg}$ body weight were injected intravenously. Blood samples for plasma glucose were taken $-30,-15,0,5,10,15,20,25,30,35$, 40 and $45 \mathrm{~min}$ after insulin injection. The insulin sensitivity was expressed as the rate constant for plasma glucose disappearance $\mathrm{k}_{\mathrm{IVTT}}=\ln 2 / \mathrm{T}^{1} / 2$, in which $\mathrm{T}^{1 / 2}=$ half life time of the exponential decline of the plasma glucose concentration between 5 min and 30 min after insulin injection.

\section{Statistical Methods}

Wilcoxon's test for paired differences was employed for comparison of values before and after change of diet, while Spearman's coefficient of rank ( $R$ ) was applied in correlation studies. Results in figures and tables are given as mean values \pm SEM.

\section{Results}

In the total group of volunteers we have studied the relationship between insulin binding to monocytes and food intake before the change of diet. Table 3 shows significantly negative correlations between insulin binding and total daily food calories, total carbohydrate intake and sucrose intake, respectively. An insignificant interrelationship was found between insulin binding and fat intake in the total group of participants whereas the same 2 variables were significantly negatively correlated in females.

\section{Effects of Experimental Diets}

Group 1 (Hypercaloric, high-sucrose diet). The cellular insulin binding at tracer concentration was lowered already after 1 week and after 2 weeks dieting the insulin binding was approximately $60 \%$ of the initial value $(p<0.05)$ (Table 1$)$. It appears from the Scatchard plot (Fig. 1 b) that a possible reduction of the receptor concentration occurred $(p<0.1)$ and from the corresponding competition curve (Fig. 1 a) 
Table 3. Correlations between specific cell bound fraction and daily intake of total food, fat, carbohydrates and sucrose before change of diet. The total number of subjects is only 27 as the food record of one female was incomplete

\begin{tabular}{|c|c|c|c|c|c|}
\hline & & $\begin{array}{l}\text { Total food } \\
\text { intake } \\
\text { (kcal/day) }\end{array}$ & $\begin{array}{l}\text { Total fat } \\
\text { intake } \\
\text { (kcal/day) }\end{array}$ & $\begin{array}{l}\text { Total carbohydrate } \\
\text { intake } \\
\text { (kcal/day) }\end{array}$ & $\begin{array}{l}\text { Total sucrose } \\
\text { intake } \\
\text { (kcal/day) }\end{array}$ \\
\hline \multirow{3}{*}{$\begin{array}{l}\text { Specific cell } \\
\text { bound fraction } \\
\text { of }{ }^{125} \text { I-insulin }\end{array}$} & $\begin{array}{l}\sigma^{n}+ \\
(n=27)\end{array}$ & $\begin{array}{l}\mathbf{R}=-0.40 \\
(p<0.05)\end{array}$ & $\begin{array}{l}\mathrm{R}=-0.25 \\
(\mathrm{p}>0.1)\end{array}$ & $\begin{array}{l}R=-0.45 \\
(p<0.05)\end{array}$ & $\begin{array}{l}\mathrm{R}=-0.52 \\
(\mathrm{p}<0.01)\end{array}$ \\
\hline & $\begin{array}{l}\stackrel{9}{+} \\
(n=20)\end{array}$ & $\begin{array}{l}R=-0.60 \\
(p<0.02)\end{array}$ & $\begin{array}{l}\mathbf{R}=-0.42 \\
(\mathrm{p}<0.05)\end{array}$ & $\begin{array}{l}\mathrm{R}=-0.58 \\
(\mathrm{p}<0.02)\end{array}$ & $\begin{array}{l}\mathbf{R}=-0.64 \\
(\mathrm{p}<0.01)\end{array}$ \\
\hline & $\begin{array}{l}\sigma^{\prime} \\
(\mathrm{n}=7)\end{array}$ & $\begin{array}{l}R=-0.30 \\
(p>0.1)\end{array}$ & $\begin{array}{l}R=-0.50 \\
(p>0.1)\end{array}$ & $\begin{array}{l}R=-0.21 \\
(p>0.1)\end{array}$ & $\begin{array}{l}\mathbf{R}=-0.54 \\
(p>0.1\end{array}$ \\
\hline
\end{tabular}

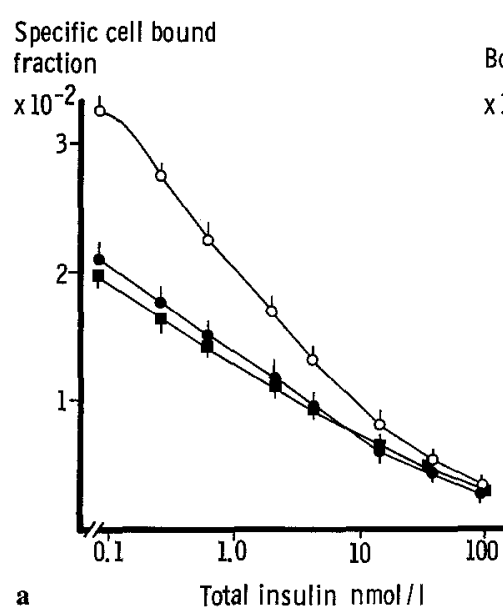

it is evident also that apparent receptor affinity decreased $(\mathrm{p}<0.05)$ since $50 \%$-inhibition of $125 \mathrm{I}$ insulin binding was achieved at $2.0 \mathrm{nmol} / 1$ insulin in the baseline period and at $2.6 \mathrm{nmol} / 12$ weeks after the start of the hypercaloric period. At the end of the diet study the fasting plasma insulin concentration was increased about 50\% $(\mathrm{p}<0.05$, Table 1) whereas the insulin sensitivity (Fig. 2 and Table 1) was significantly impaired $(\mathrm{p}<0.05)$. Before the change of diet the coefficient of correlation $(\mathrm{R})$ for the relationship between the insulin sensitivity and the insulin binding at insulin tracer concentration was $0.50, p>0.1$ (Fig. 3) while the R-value increased to $0.95, \mathrm{p}<0.05$ (Fig. 3) after hyperalimentation of sucrose. Weight gain averaged $1.5 \mathrm{~kg}(\mathrm{p}<0.05)$.

Group 2 (Hypercaloric, high-fat diet). The effect of 2 weeks increased fat intake on the insulin binding to monocytes is given in Table 1 . The specific cell bound fraction at tracer concentration was depressed $22 \%$ $(\mathrm{p}<0.05)$. The competition curve (Fig. 4 a) indi-
Fig. 1. Insulin binding to monocytes in 6 normal subjects: effect of hypercaloric sucrose feeding. Subjects were studied on their usual diet and after 7 days and again after 14 days, respectively, when fed their usual diet with addition of $1000 \mathrm{kcal}$ sucrose per day. Mononuclear leucocytes were incubated with ${ }^{125}$ Y-insulin $(85 \mathrm{pmol} / \mathrm{l})$ and native insulin in increasing concentrations.

Radioactivity bound in the presence of $13 \mu \mathrm{mol} / \mathrm{l}$ unlabelled insulin was called nonspecific cell binding. Total binding minus nonspecific binding gives the specific cell bound fraction. Cell bound fractions were corrected to a monocyte concentration of $1.2 \times 10^{7} / \mathrm{ml}$.

a Specific cell bound fraction of ${ }^{125} \mathrm{I}$-insulin as a function of native insulin. b Scatchard analysis of the binding data from, a. Maximal binding capacity, $\mathbf{R}_{\mathrm{o}}$, was obtained by extrapolation of each curve to the abscissa cated that this decrease was due to a lowering of the receptor affinity as $50 \%$-inhibition of tracer bound insulin was obtained at $2.0 \mathrm{nmol} / 1$ insulin before and at $4.0 \mathrm{nmol} / 1$ insulin after the hypercaloric regimen $(p<0.05)$. Scatchard analysis of the binding data (Fig. 4 b) revealed a non-significant increase ( $p>$ 0.1 ) of receptor concentration. Compared to baseline, mean fasting plasma level of insulin was unchanged (Table 1). The insulin sensitivity was unaffected by the high fat intake (Fig. 2 and Table 1). Average weight gain was $1.5 \mathrm{~kg}(\mathrm{p}<0.05)$.

Group 3 (Isocaloric, low-sucrose, high-fat diet). One week after the start of this diet there was no significant change in the specific cell bound fraction at tracer concentration (Table 1) whereas a significant rise of the same variable occurred at the end of the second week $(p<0.05)$. Figure 5 shows that the rise in insulin binding was caused by an increase of receptor concentration $(p<0.05)$ without any change of receptor affinity. Fasting plasma insulin concentra- 


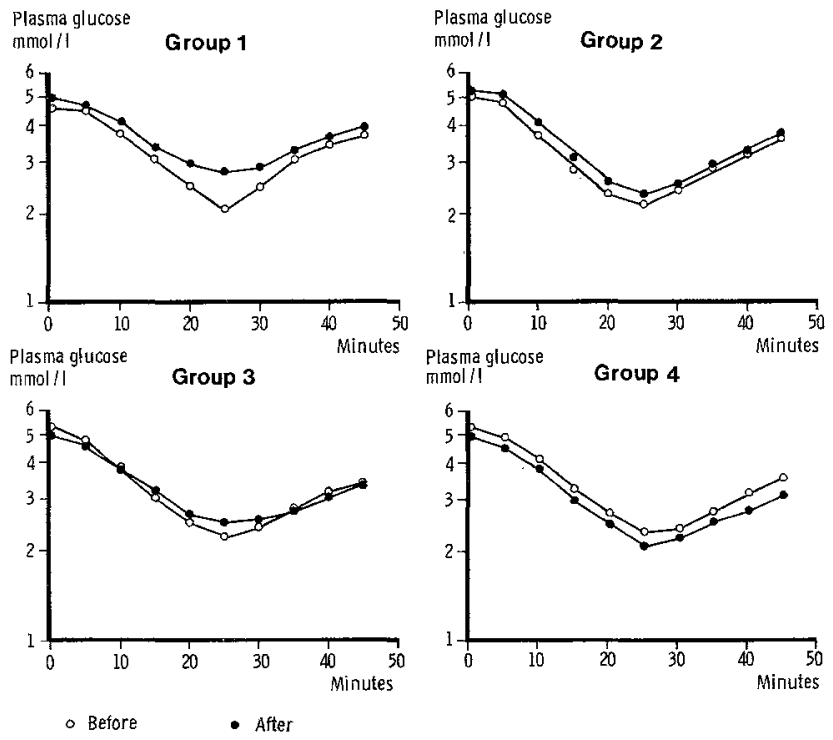

Fig. 2. Insulin tolerance tests for the 4 groups studied before and 14 days after change of diet (group 1: hypercaloric sucrose diet, group 2: hypercaloric fat diet, group 3: isocaloric low sucrose diet and group 4: isocaloric low fat diet). The plasma glucose concentration is plotted as a function of time after IV injection of $0.05 \mathrm{U}$ insulin per $\mathrm{kg}$ body weight at time zero

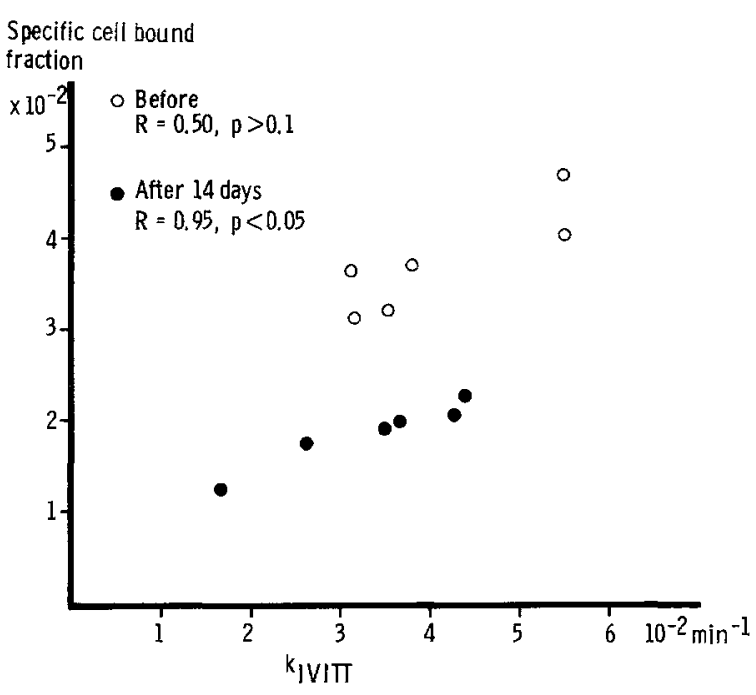

Fig. 3. Correlation between $\mathrm{k}_{\text {IVTTT }}$ and the specific cell bound fraction of ${ }^{125}$ I-insulin ( $85 \mathrm{pmol} / \mathrm{l}$ ) for group 1 (hypercaloric sucrose diet). For details see legend to Figure 1 and Figure 2
Specific cell bound fraction

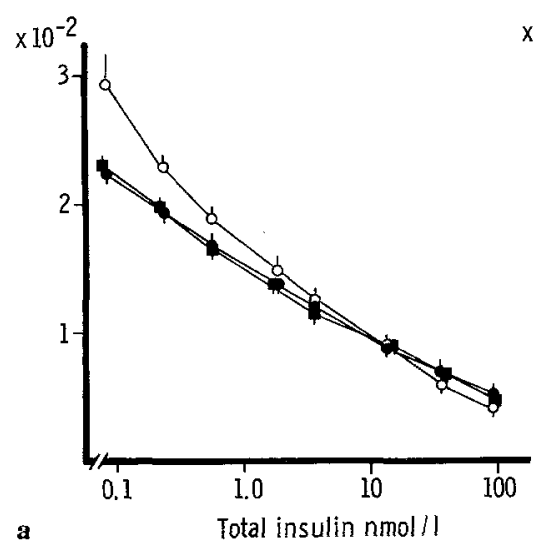

Bound / free insulin

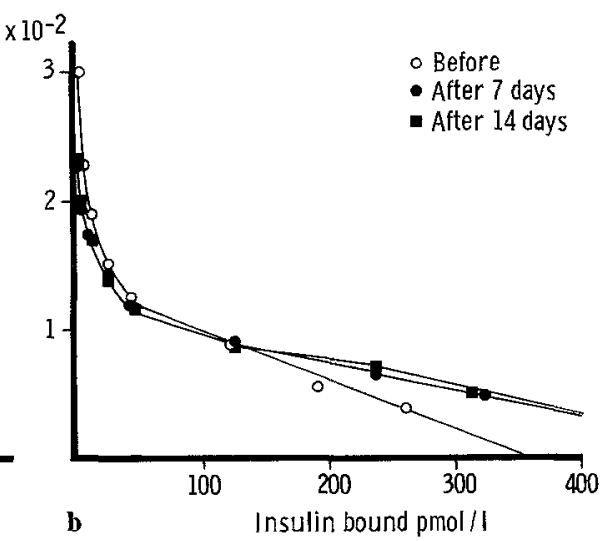

Fig. 4. Insulin binding to monocytes from 6 normal subjects: effect of hypercaloric fat feeding. Subjects were studied on their usual diet and after 7 days and again after 14 days, respectively, when fed their usual diet plus 1000 extra kcal per day arising from cream. Experimental conditions as described in legend to Figure 1.

a Specific cell bound fraction of ${ }^{125} \mathrm{I}$-insulin as a function of native insulin.

b Scatchard analysis of the binding data derived from, a. Maximal binding capacity, $R_{0}$, was obtained by extrapolation of each curve to the abscissa tion, insulin sensitivity and average body weight were unchanged $(\mathrm{p}>0.1)$.

Group 4 (Isocaloric, low-fat, high-polysaccharide diet). No significant change in insulin binding at tracer concentration $(p>0.1)$ was found after 2 weeks dieting (Table 1). No significant changes of receptor number $(\mathrm{p}>0.1)$ or receptor affinity $(\mathrm{p}>$ 0.1 ) occurred (Fig. 2). The fasting plasma insulin level remained constant whereas the insulin sensitivity (Table 1 and Fig. 2 ) improved significantly ( $<<$ $0.05)$. Body weight was kept constant $(\mathrm{p}>0.1)$.
Controls. No significant changes occurred in insulin binding $(\mathrm{p}>0.1)$, in fasting plasma concentration of insulin $(p>0.1)$ or in body weight $(p>0.1)$ (Table 1 and Fig. 7).

\section{Discussion}

The results of this report demonstrate that diets with different composition and calorie content given to healthy young subjects lead to adaptive changes in cellular insulin binding and in metabolic variables. 


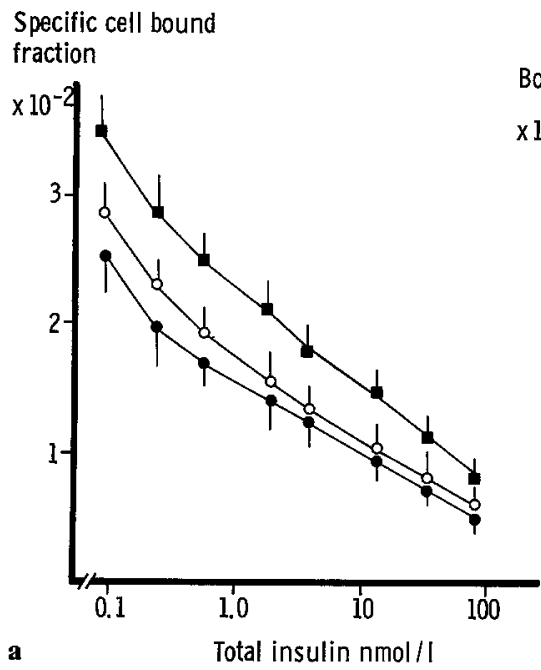

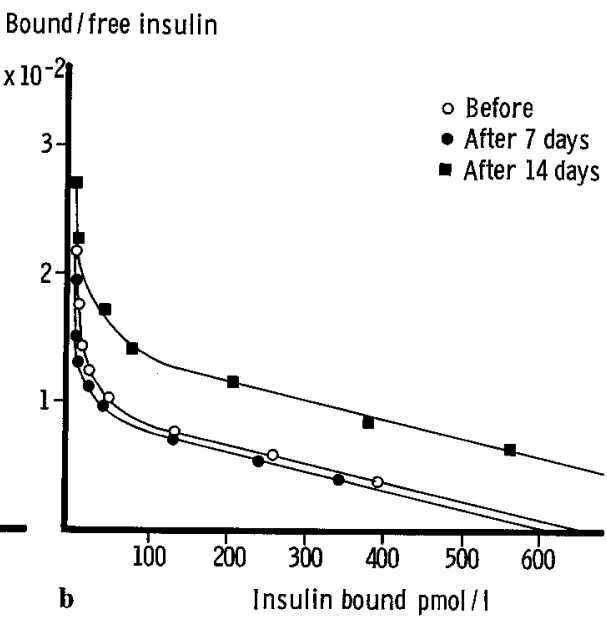

Fig. 5. Insulin binding to monocytes from 6 normal subjects: effect of isocaloric low-sucrose feeding. Subjects were studied on their usual diet and after 7 days and again after 14 days, respectively, when fed isocaloric but low-sucrose diets. Experimental conditions as described in legend to Figure 1. a Specific cell bound fraction of ${ }^{125} \mathrm{I}$-insulin as a function of native insulin. b Scatchard analysis of the binding data derived from, a. Maximal binding capacity, $\mathbf{R}_{\mathrm{o}}$, was obtained by extrapolation of each curve to the abscissa

Specific cell bound

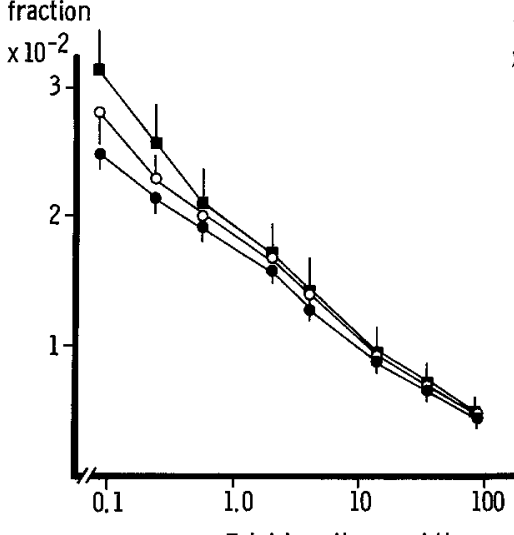

a

Total insulin nmol/l

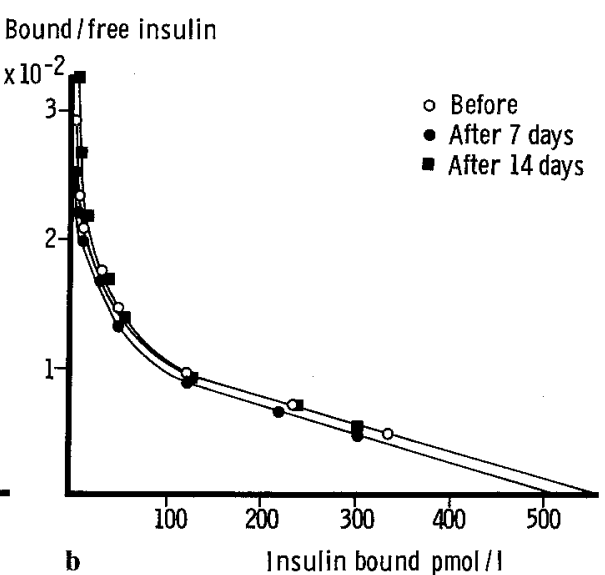

Fig. 6. Insulin binding to monocytes from 6 normal subjects: effect of isocaloric low-fat feeding. Subjects were studied on their usual diets and after 7 days and again after 14 days, respectively, when fed isocaloric but low-fat diets. Experimental conditions as described in legend to Figure 1.

a Specific cell bound fraction of ${ }^{125}$ I-insulin as a function of native insulin.

b Scatchard analysis of the binding data derived from, a. Maximal binding capacity, $\mathbf{R}_{0}$, was obtained by extrapolation of each curve to the abscissa

Specific cell bound fraction

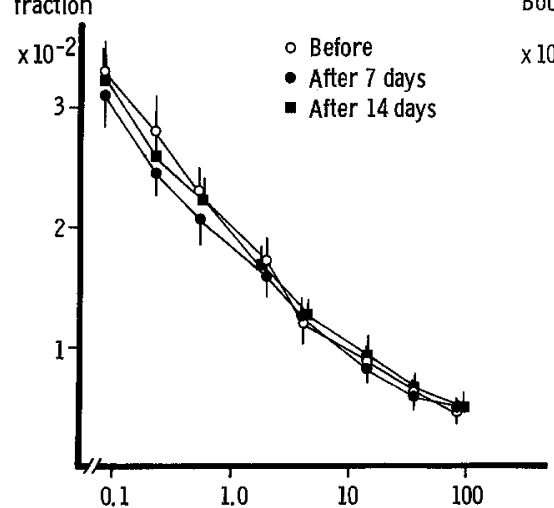

a

Total insulin $\mathrm{nmol} / \mathrm{I}$
Bound / free insulin

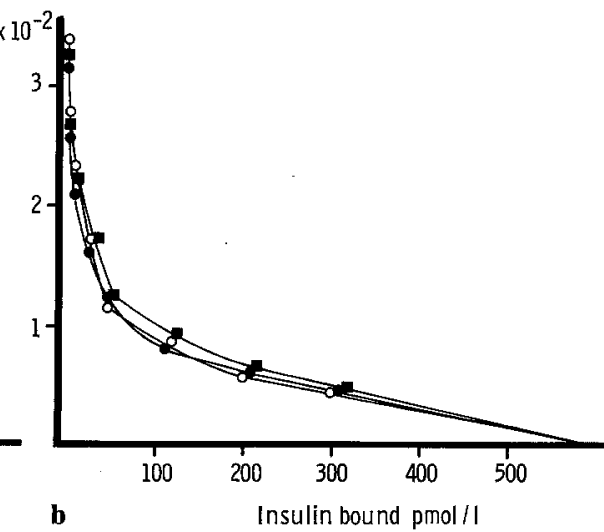

Fig. 7. Insulin binding to monocytes from 4 control subjects eating an unchanged diet. a Specific cell bound fraction of ${ }^{125}$ I-insulin as a function of native insulin.

b Scatchard analysis of the binding data derived from, a. Maximal binding capacity, $R_{0}$, was obtained by extrapolation of each curve to the abscissa 
During the baseline period insulin binding was inversely correlated to the total daily food intake and most notably to the sucrose content of the diet. The effect of dietary sucrose on insulin binding to monocytes was further supported by the finding that ingestion of $250 \mathrm{~g}$ extra sucrose per day was followed by a $40 \%$ fall in insulin binding, whereas a reduction of the sucrose consumption was associated with a $30 \%$ increase in insulin binding. On the other hand hypercaloric, high fat-containing diets depressed insulin binding only about $20 \%$. Isocaloric diets with low-fat content did not affect insulin binding significantly. However, the increase of dietary sucrose in group 4 (Table 2) may have diminished the expected rise in cellular insulin binding of this group.

No changes of insulin binding occurred in controls. Thus we conclude that the observed alterations of insulin binding to monocytes isolated from persons who had their diet changed are real and neither caused by methodological errors nor by day to day variation.

Scatchard analysis of the competition studies showed curvilinear plots (Figs. 1, 4, 5, 6). Whether this configuration of Scatchard plots is due to negative cooperativity among binding sites or the existence of more binding sites with different affinity and capacity is currently discussed [18]. Therefore we have applied " $50 \%$ inhibition" (see 'methods') as a crude estimate of apparent receptor affinity. Moreover, we have used the extrapolated intercept on the $x$-axis of the Scatchard plot as an estimate of the maximal binding capacity, $R_{0}$, because $R_{o}$ is the same no matter which of the two interpretations is preferred. Analysed in this manner we found a reduction of the binding affinity $(\mathrm{p}<0.05)$ and perhaps of the binding capacity $(p<0.1)$ following hyperalimentation of sucrose while a rise of binding capacity $(\mathrm{p}<0.05)$ occurred after low-sucrose feeding. Hypercaloric fat feeding was associated with a reduction of the binding affinity $(\mathrm{p}<0.05)$. However, these conclusions are made with certain reservations because of the difficulties in the interpretation of the Scatchard plots and the small study groups.

Ip et al. [19] have reported adaptive changes in insulin receptors on adipocytes from rats fed a fat diet. Cells from rats adapted to fat feeding bound less insulin compared to those from rats fed a glucose diet. However, Cushman and Salans [20] could not detect any difference in insulin binding when adipocytes from fat-fed rats were compared with those fed a high-carbohydrate diet. Dahms et al. [21] have explored the effect of high-fat and high-carbohydrate but isocaloric diets on the insulin binding to adipo- cytes in obese adults. No difference between binding to fat cells on either of the two diets were obtained. The results of Dahms et al. may be compared to those derived from group 4 in the present study in which we found no significant change in insulin binding to monocytes following a raised dietary carbohydrate: lipid ratio. Actually there is no direct discrepancy between the results of Dahms et al. and ours. On the other hand the results reported by Ip et al. [19] and Cushman and Salans [20] differ from ours (group 1 and 2). In this context the difference in protocol and diet should be remembered.

Our data suggest that the insulin receptor on monocytes is sensitive to changes of the diet. The mechanism for this receptor modulation is unclear. However, evidence is accumulating that insulin binding is inversely regulated by the ambient insulin concentration [22]. In the present study we found that manipulations of the dietary sucrose (group 1 and 3) were associated with inverse changes of the plasma insulin concentration and the insulin binding to monocytes supporting the idea that sucrose might influence the cellular insulin binding through the plasma levels of insulin. However, no inverse changes of the same two variables occurred in group 2 so we conclude that plasma insulin under certain conditions may be but one of many receptor regulatory factors.

Recently several studies have shown that insulin binding and insulin sensitivity are related [8, 9]. These findings were confirmed in this study where a positive correlation between cellular insulin binding and insulin sensitivity was demonstrable before the change of diet $(\mathrm{R}=0.56, \mathrm{p}<0.01)$. We have estimated changes both in insulin binding and insulin sensitivity under dietary manipulations. In group 1 we found parallel changes in the two variables. The correlation coefficient (R) increased from 0.50 to 0.95 during the diet period which indicates that the changes in insulin sensitivity during sucrose feeding can largely be explained by changes in insulin binding. Comparable changes in insulin binding and insulin sensitivity occurred in group 4. Conversely, there were no parallel changes in the groups with a high lipid: carbohydrate ratio (group 2 and 3 ), which is in keeping with results obtained during fasting [23] where the two variables diverge. The changes in insulin sensitivity in groups 2 and 3, therefore, must be related to alterations of factors other than insulin receptors e. g. intracellular enzymes. Our conclusions assume that changes of insulin receptors on insulin target tissues occur parallel to changes in monocytes. Indeed, experimental data are available to support this assumption [24]. 
Acknowledgements. We are indebted to the dietitians Inger Marie Jørgensen and Ulla Vinther and to the laboratory workers T. Skrumsager, L. Busch and L. Blak for skillful assistance, and L. Thomsen for her careful preparation of the manuscript. The study was supported by grants from Danish Medical Research Council, Landsforeningen for Sukkersyges Fond, Nordisk Insulin Fond and NOVO Fond.

\section{References}

1. Himsworth, H. P.: Dietetic factors determining the glucose tolerance and sensitivity to insulin of healthy man. Clin. Sci. Mol. Med. 2, 67-94 (1935)

2. Wilkerson, H. L. C., Hyman, H., Kaufman, M., McCuistion, A. C., O'S Francis, J.: Diagnostic evaluation of oral glucose tolerance tests in nondiabetic subjects after various levels of carbohydrate intake. N. Engl. J. Med. 262, 1047-1053 (1960)

3. Anderson, J.W., Herman, R. H.: Effect of fasting, caloric restriction, and refeeding on glucose tolerance of normal men. Am. J. Clin. Nutr. 25, 41-52 (1972)

4. Sims, E. A. H., Danforth, E., Jr., Horton, E. S., Bray, G. A., Glennon, J. A., Salans, L. B.: Endocrine and metabolic effects of experimental obesity in man. Recent Prog. Horm. Res. 29, 457-494 (1973)

5. Szanto, S., Yudkin, J.: The effect of dietary sucrose on blood lipids, serum insulin, platelet adhesiveness and body weight in human volunteers. Postgrad. Med. J. 45, 602-607 (1969)

6. Olefsky, J. M.: The insulin receptor: Its role in insulin resistance of obesity and diabetes (Review). Diabetes 25, 1154-1161 (1977)

7. Beck-Nielsen, H.: The pathogenic role of an insulin receptor defect in diabetes mellitus of obese. Diabetes (in press)

8. Harrison, L. C., Martin, F. I. R., Melick, R. A.: Insulin receptor binding in isolated fat cells and insulin sensitivity in obese. J. Clin. Invest. 58, 1435-1441 (1976)

9. Beck-Nielsen, H., Pedersen, O.: Insulin receptors on monocytes of young healthy persons correlated to glucose tolerance and insulin sensitivity. Diabetologia 14, 159-163 (1978)

10. Helms, P.: Fødevaretabeller. Copenhagen: Akademisk Forlag 1973

11. Heding, L.G.: A simplified insulin radioimmunoassay method. In: L. Donato et al. (Ed.): Labelled proteins in tracer studies 329-333. Brussels: Euratom 1966

12. Feteris, W. A.: A serum glucose method without protein precipitation. Am. J. Med. Technol. 31, 17-21 (1965)
13. Pedersen, O., Beck-Nielsen, H.: A study of insulin receptors in human mononuclear leucocytes. Acta Endocrinol. (Kbh.) 83, 556-564 (1976)

14. Jørgensen, K. H., Binder, C.: ${ }^{125} \mathrm{I}$-insulin as a tracer of insulin in different chemical processes. In: L. Donato et al. (Ed.): Labelled proteins in tracer studies, 329-333. Brussels: Euratom 1966

15. Freychet, P., Roth, J., Neville, D. M. Jr.: Monoiodoinsulin: demonstration of its biological activity and binding to fat cells and liver membranes. Biochem. Biophys. Res. Commun. 43, 400-408 (1966)

16. Beck-Nielsen, H., Pedersen, O., Kragballe, K., Sørensen, N. S.: The monocyte as a model for the study of insulin receptors in man. Diabetologia 13, 563-569 (1977)

17. Scatchard, G.: The attractions of proteins for small molecules and ions. Ann. N. Y. Acad. Sci. 51, 660-672 (1949)

18. Pollet, R. J., Standaert, M. L., Haase, B. A.: Insulin binding to the human lymphocyte receptor. J. Biol. Chem. 252, 5828-5834 (1977)

19. Ip, C., Tepperman, H. M., Holohan, P., Tepperman, J.: Insulin binding and insulin response of adipocytes from rats adapted to fat feeding. J. Lipid Res. 17, 588-599 (1976)

20. Cushman, S. W., Salans, L. B.: Effects of dietary composition on insulin binding in isolated rat adipocytes (Abstract). Clin. Res. 23, 317 (1975)

21. Dahms, W. T., Atkinson, R. L., Bray, G. A.: Insulin resistance and the binding of insulin to adipocytes (Abstract). Clin. Res. 24, 116 (1976)

22. Gavin, J. R., III, Roth, J., Neville, D. M. Jr., De Meyts, P., Buell, D. N.: Insulin-dependent regulation of insulin receptor concentrations. A direct demonstration in cell culture. Proc. Natl. Acad. Sci. USA 71, 84-88 (1974)

23. Olefsky, J.M.: Effects of fasting on insulin binding, glucose transport, and glucose oxidation in isolated rat adipocytes: relationship between insulin binding and insulin action. J. Clin. Invest. 58, 1450-1460 (1977)

24. Olefsky, J. M.: Decreased insulin binding to adipocytes and circulating monocytes from obese subjects. J. Clin. Invest. 57, 1165-1172 (1976)

Received: January 23, 1978, and in revised form: April 14, 1978

Dr. H. Beck-Nielsen

Medical Department III

County Hospital

Tage Hansensgade

DK-8000 Aarhus C, Denmark 